\title{
COVID-19 and Refractive Errors: A New Potential Threat for Children and Adolescents
}

\author{
Lorenzo Ferro Desideri ${ }^{1 \star}$, Fabio Barra ${ }^{1}$, Marcos Roberto Tovani-Palone ${ }^{2^{\star \star}}$
}

${ }^{1}$ IRCCS Polyclinic San Martino Hospital, University Eye Clinic, Genoa, ITALY

${ }^{2}$ Ribeirão Preto Medical School, University of São Paulo, Ribeirão Preto, BRAZIL

${ }^{\star}$ Corresponding Author: lorenzoferrodes@gmail.com

${ }^{\star \star}$ Corresponding Author: marcos_palone@hotmail.com

Citation: Desideri LF, Barra F, Tovani-Palone MR. COVID-19 and Refractive Errors: A New Potential Threat for Children and Adolescents. Electron J Gen Med. 2021;18(4):em300. https://doi.org/10.29333/ejgm/10870

\begin{tabular}{|c|c|}
\hline ARTICLE INFO & ABSTRACT \\
\hline Received: 2 Dec. 2020 & The current pandemic has changed the social life and learning of most children and adolescents around the world \\
\hline Accepted: 1 Feb. 2021 & $\begin{array}{l}\text { due to public health restrictions. In response to this, they have spent more time on computer and television } \\
\text { monitor screens, which should negatively impact their eye health. Thus, here we discuss the possible association } \\
\text { between the imposed home confinement and risk of developing 'quarantine myopia' in children and adolescents. }\end{array}$ \\
\hline
\end{tabular}

Keywords: COVID-19, SARS-CoV-2, pandemics, myopia, child

Dear Editor,

The present global epidemic of coronavirus disease 2019 (COVID-19) represents a major threat to public health worldwide [1-3]. The virus that causes the disease was named severe acute respiratory syndrome coronavirus 2 (SARS-CoV2 ), and it is characterized by high transmissibility (3-and 10-fold higher than those of severe acute respiratory syndrome coronavirus (SARS-CoV) and Middle east respiratory syndrome coronavirus (MERS-CoV)), which has been proven to be directly related to the sequence of the $S$ protein of the virus [4]. Given the current scenario, governments all over the world have imposed strong public health restrictions, including social distancing, travel prohibitions, and quarantines, in order to decrease the impact of the epidemic on the population as well as on global healthcare systems [5-7]. Given this and the increasing number of SARS-CoV-2 infections, the population lifestyle is forcefully subjected to significant modifications, including decreased physical activity levels, irregular sleep habits [8] and, importantly, more time spent on computer and television monitor screens [9].

From an ophthalmological perspective, a new concern is emerging: the possible association between the imposed home confinement and risk of developing 'quarantine myopia' in children and adolescents [10]. In fact, it has been largely demonstrated that myopia progression is related to intense near-work activity, an increased screen-time and, notably, to the reduced possibility of doing outdoor activities (due to quarantine restrictions) [11]. In this regard, although there is still no consistent evidence about the pathogenic mechanism at the base of myopia progression in children doing less outdoor activities and more near-work activity, preclinical models have shown that this could be associated with an altered dopamine metabolism in the ocular tissues [12].
According to the United Nations Educational, Scientific, and Cultural Organization (UNESCO), around $80 \%$ of the schools have been closed worldwide in more than 138 countries in the attempt of containing SARS-CoV-2 infection [13]. Thus, in order to respond to this situation and ensure children and adolescents' education, many national governments have made a massive effort of creating online courses delivered by TV broadcasts or internet [9]. Nonetheless, in some Asian eastern countries (such as China) the prevalence of myopia has rapidly grown in the last years due to the replacement of books with tablets and computers in schools [14]. In this sense, the World Health Organization (WHO) has already elaborated recommendations on sedentary screen time for children younger than 5 years old, because of the possible negative impact on their overall health, including the augmented risk of developing digital eye strain, mental and musculoskeletal disorders, and diabetes [15].

Given this background, a prolonged time of home quarantine could represent a non-negligible risk factor for the increased onset and progression of myopia in children and adolescents. In fact, children and adolescents confined at home are more likely inclined to spend more time on TV and computers, which increases the time spent on near-work activities and decreases the time on outdoor activities. For these reasons, important concerns are raised for the possible increased progression of myopia in children, especially in lowdeveloped countries, representing an important cause of visual impairment in these population groups. Moreover, this would also lead to an increased incidence of high-myopia and its possible severe ocular complications in older patients in the future.

Thus, we deem that a myopia screening strategy with a complete ophthalmological examination should be encouraged for these children and adolescents, by stratifying 
the risk in relation to demographic and clinical features. In addition to this, appropriate educational strategies in this direction should also be developed, including a revision in different levels and modalities of the educational system, as well as the development of a more solid awareness for both the parents and children of their ocular health.

Author contributions: All authors have sufficiently contributed to the study, and agreed with the results and conclusions.

Funding: No funding source is reported for this study.

Declaration of interest: No conflict of interest is declared by authors.

\section{REFERENCES}

1. Akhtar N. COVID-19 in Pakistan: current scenario and future perspective. J Clin Exp Invest. 2020;11(4):em00753. https://doi.org/10.29333/jcei/8354

2. Santacroce L, Charitos IA, Prete RD. COVID-19 in Italy: an overview from the first case to date. Electron J Gen Med. 2020;17(6): em235. https://doi.org/10.29333/ejgm/7926

3. Tovani-Palone MR, Lacagnina S, Ferro Desideri L. Number of COVID-19 patients classified as cured: an imminent danger for the population. einstein (São Paulo). 2020;18:eCE6146. https://doi.org/10.31744/einstein_jour nal/2020CE6146 PMid:33111812

4. Pillay TS. Gene of the month: the 2019-nCoV/SARS-CoV-2 novel coronavirus spike protein. J Clin Pathol. 2020;73(7):366-9. https://doi.org/10.1136/jclinpath-2020206658 PMid:32376714

5. Musinguzi G, Asamoah BO. The science of social distancing and total lock down: does it work? Whom does it benefit? Electron J Gen Med. 2020;17(6):em230. https://doi.org/ 10.29333/ejgm/7895

6. Musinguzi G, Asamoah BO. The COVID-19 Lockdown trap, how do we get out?. J Clin Exp Invest. 2020;11(4):em00752. https://doi.org/10.29333/jcei/8343

7. Vagge A, Ferro Desideri L, lester M, Del Noce C, Catti C, Musolino $\mathrm{M}$, et al. Management of pediatric ophthalmology patients during the COVID-19 outbreak: experience from an Italian tertiary eye center. J Pediatr Ophthalmol Strabismus. 2020;57(4):213-6. https://doi.org/10.3928/ 01913913-20200513-01 PMid:32687204
8. Ammar A, Brach M, Trabelsi K, Chtourou H, Boukhris O, Masmoudi L, et al. Effects of COVID-19 home confinement on eating behaviour and physical sctivity: results of the ECLB-COVID19 International Online Survey. Nutrients. 2020;12(6):1583. https://doi.org/10.3390/nu12061583 PMid:32481594 PMCid:PMC7352706

9. Wang G, Zhang Y, Zhao J, Zhang J, Jiang F. Mitigate the effects of home confinement on children during the COVID19 outbreak. Lancet. 2020;395(10228):945-7. https://doi.org/10.1016/S0140-6736(20)30547-X

10. Sumitha M, Sanjay S, Kemmanu V, Bhanumathi MR, Shetty R. Will COVID-19 pandemic-associated lockdown increase myopia in Indian children? Indian J Ophthalmol. 2020;68(7):1496. https://doi.org/10.4103/ijo.IJO_1443_20

11. Lin Z, Gao TY, Vasudevan B, Ciuffreda KJ, Liang YB, Jhanji V, et al. Near work, outdoor activity, and myopia in children in rural China: the Handan offspring myopia study. BMC Ophthalmol. 2017;17(1):203. https://doi.org/10.1186/ s12886-017-0598-9 PMid:29149871 PMCid:PMC5693484

12. Rose KA, Morgan IG, Ip J, Kifley A, Huynh S, Smith W, et al. Outdoor activity reduces the prevalence of myopia in children. Ophthalmology. 2008;115(8):1279-85. https://doi.org/10.1186/s12886-017-0598-9 PMid:29149871 PMCid:PMC5693484

13. Van Lancker W, Parolin Z. COVID-19, school closures, and child poverty: a social crisis in the making. Lancet Public Health. 2020;5(5):e243-e4. https://doi.org/10.1016/S24682667(20)30084-0

14. Lin Z, Vasudevan B, Mao GY, Ciuffreda KJ, Jhanji V, Li XX, et al. The influence of near work on myopic refractive change in urban students in Beijing: a three-year follow-up report. Graefes Arch Clin Exp Ophthalmol. 2016;254(11):2247-55. https://doi.org/10.1186/s12886-017-0598-9 PMid:29149871 PMCid:PMC5693484

15. Singh NK. Letter to the editor: myopia epidemic postcoronavirus disease 2019. Optom Vis Sci. 2020;97(10):9112. https://doi.org/10.1097/opx.0000000000001591 PMid: 33109946 